7. Reprod. Fert. (1973) 33, 441-450

\title{
THE UNUSUAL EFFECT OF GONADECTOMY ON PITUITARY GONADOTROPHINS IN THE MALE BOVINE
}

\author{
A. F. PARLOW, C. M. BAILEY AND W. DARRELL FOOTE
}

Department of Obstetrics and Gynecology, University of California (Los Angeles) School of Medicine, Harbor General Hospital Campus, Torrance, California 90509, and Department of Animal Science, University of Nevada, Reno, Nevada, U.S.A.

(Received 15th May 1972)

Summary. The concentration of FSH and LH was determined in individual anterior pituitaries of the 'intact' (bull) and gonadectomized (steer) male bovine, by differential biological assay methods. The validity of the use of NIH-FSH-ovine and NIH-LH-ovine reference preparations for these bioassays was established. The mean FSH concentration for two groups of bulls was very low: $1.4 \mu \mathrm{g}$ and $2 \cdot 1 \mu \mathrm{g}$ NIH-FSH-S1/mg dry weight. By comparison with male rat anterior pituitary FSH concentration, bull FSH concentration was approximately one hundred times lower, so that the total amounts of FSH in a bull and in a rat anterior pituitary are approximately equivalent. The mean LH concentration for two groups of bulls was rather high : 10.5 and $13.5 \mu \mathrm{g} \mathrm{NIH-LH-S1/mg}$ dry weight. Measured approximately 1 year after gonadectomy, steer anterior pituitary FSH concentration had approximately doubled while the anterior pituitary LH concentration had decreased to less than half that in the 'intact' bull. This response of male bovine pituitary LH to the effect of long-term gonadectomy contrasts strikingly with the response of the male rat, in which pituitary $\mathrm{LH}$ increases five to tenfold after gonadectomy. These data support the concept of species differences in the mode of regulation of pituitary gonadotrophins.

\section{INTRODUCTION}

Bovine gonadotrophins have been a particularly intriguing subject for study, because of the unusually low concentration of FSH in the pituitary gland of this species. We have examined the influence of gonadectomy in the male bovine on the concentrations of pituitary FSH and LH as a means of gauging the responsiveness of the bovine pituitary gland to a major alteration of the normal pituitary-gonadal interrelationship. An additional purpose of this study was to compare the influence of gonadectomy on pituitary FSH and LH in the bovine with its influence on pituitary FSH and LH in other species, as a means of discerning species differences in the regulation of pituitary gonadotrophins. Pituitary FSH and $\mathrm{LH}$ concentrations following the implantation of stilboestrol were also determined. 


\section{MATERIALS AND METHODS}

Fifty-eight bull calves from the Nevada Agricultural Experiment Station were used. Forty of these were grade Herefords and eighteen were pure-bred Herefords.

\section{Experimental schedules}

Grade Herefords. Twenty-one of these forty, randomly selected bull calves were castrated during June 1963, at a mean age of 91 days. After a post-weaning adjustment period, the calves received a 'growing' ration for 112 days. At the end of this period, ten of the nineteen bull calves, selected at random, received implants of stilboestrol $(60 \mathrm{mg} / \mathrm{calf})$. At approximately the same time, eleven of the twenty-one steers (castrated bull calves) also received implants of stilboestrol $(24 \mathrm{mg} /$ calf $)$. All animals were then fattened to a weight at slaughter of approximately 1000 pounds. Table 1 lists the mean age and weight of each group at the time of stilboestrol implantation and slaughter.

Pure-bred Herefords. Eight yearling bulls from two closed lines received implants of stilboestrol $(60 \mathrm{mg} / \mathrm{bull}) 140$ days after weaning. Ten bulls served as untreated controls. All eighteen bulls were fattened to a weight at slaughter of approximately 950 pounds. Table 1 lists the mean age and weight of each group at the time of stilboestrol implantation and slaughter.

\section{Removal, preservation and preparation of pituitary glands for bioassay}

Pituitaries were removed from all bulls and steers within $30 \mathrm{~min}$ of slaughter. The anterior lobe was separated from the remainder of the gland and quickly frozen. Within 2 weeks thereafter, the glands were partially thawed, homogenized in distilled water, freeze-dried and stored at refrigerator temperature. Immediately before the bioassays, a portion of the freeze-dried anterior pituitary of each animal was weighed and ground in a mortar. After addition of $0.5 \mathrm{ml}$ of $0.9 \% \mathrm{NaCl}$ solution to the mortar, the freeze-dried material was thoroughly homogenized and then diluted to the concentration required for assay.

\section{Bioassays}

The concentration of FSH and $\mathrm{LH}$ of each anterior pituitary was determined individually.

Follicle-stimulating hormone. A description of the method of Steelman \& Pohley (1953) as used in our laboratories has been reported elsewhere (Parlow \& Reichert, 1963). A reference preparation, NIH-FSH-S1 (ovine), was tested in each assay at total doses of $150 \mu \mathrm{g} / \mathrm{rat}$ and $75 \mu \mathrm{g} / \mathrm{rat}$ (five rats/dose-group). Each anterior pituitary was tested at a single dose only. Usually, a total dose of $50 \mathrm{mg}$ (dry weight) of bull anterior pituitary or $40 \mathrm{mg}$ steer anterior pituitary was administered to each of two test rats. When sufficient anterior pituitary was available, it was retested in a second and even, in two cases, a third assay. The doses of the anterior pituitaries were selected to produce a mean response which fell within the working range of the reference preparation.

The total dose of bull or steer anterior pituitary was administered in a volume of $6 \mathrm{ml}$ of $0.9 \% \mathrm{NaCl}$, through the course of twice daily injections for 3 days. Because the anterior pituitary homogenates were somewhat thick, a 22-gauge 


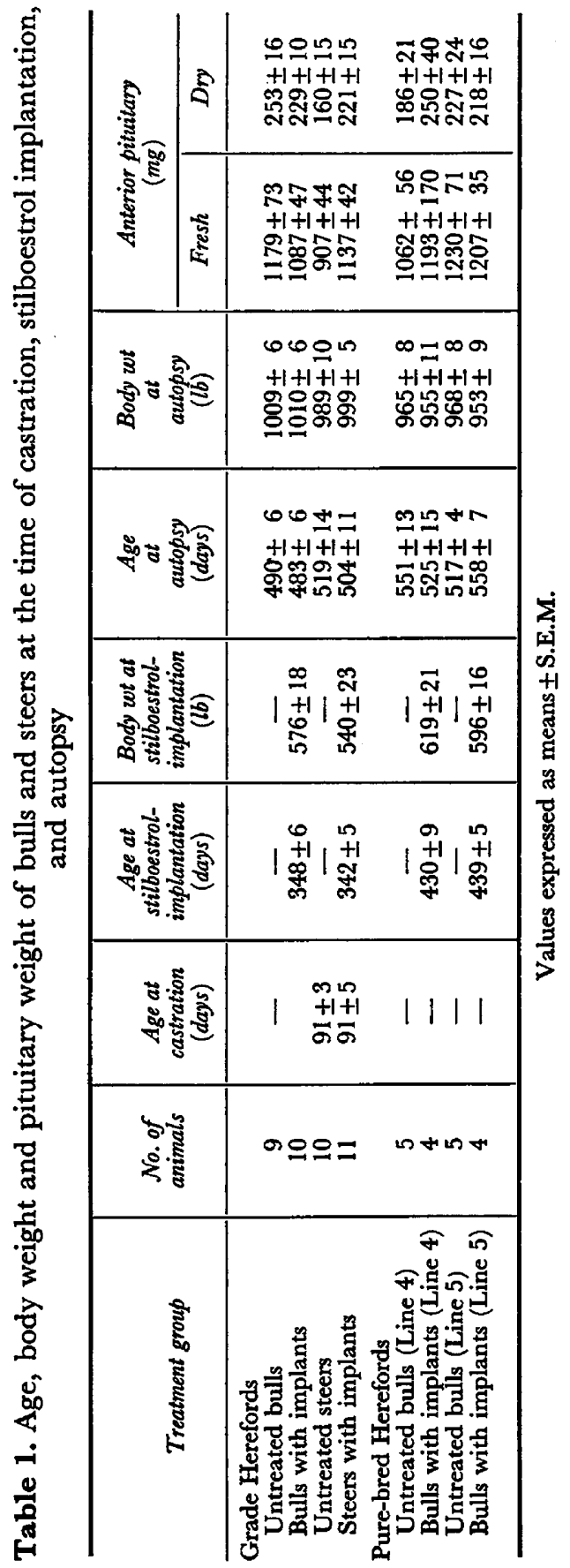


hypodermic needle was used for the subcutaneous injections. Two different injection sites were alternated each day.

Luteinizing hormone. The doses of the reference preparation (NIH-LH-Sl, ovine) used in each assay (Parlow, 1961) were 0.4 and $1.6 \mu \mathrm{g} / 100 \mathrm{~g}$ body weight (four rats/dose). Each anterior pituitary was tested at a single dose only. Since the body weights of the rats varied 20 to $25 \mathrm{~g}$ between rats, gonadotrophin was administered on a dose per unit body weight basis to reduce the variance. As a result of this 'preliminary assay', a replicate test of each anterior pituitary, at two doses, was designed. If the two potency estimates obtained thereby were significantly heterogeneous, according to the $\chi^{2}$ test, at the $P=0.05$ level, then a third assay of the anterior pituitary was undertaken, also at two doses. Anterior pituitary homogenates were slowly injected into the test rats intravenously over a period of $45 \mathrm{sec}$, to minimize toxic effects. Results of both FSH and LH assays were calculated by standard statistical methods for parallel line assays (Bliss, 1952; Sheps \& Moore, 1960).

\section{RESULTS}

Performance and validity of FSH and LH bioassays of bovine anterior pituitaries

Estimation of the concentration of FSH in the bovine anterior pituitaries was based on a single assay of each pituitary in forty-four cases, on two assays in twelve cases, and in two cases, on three assays. For the fourteen pituitaries on which at least two assays were performed, the incidence of heterogeneity of the replicate potency at $P=0.05$ was $21 \%$. Measurement of the concentration of LH was performed twice for forty-seven anterior pituitaries and three times for eleven anterior pituitaries. The incidence of heterogeneity of replicate potency estimates at $P=0.05$ was $16 \%$ for the $\mathrm{LH}$ assays. The error between the replicate estimates was incorporated into the calculation of the $95 \%$ confidence limits of the mean estimate. This procedure was followed also for computation of the mean and $95 \%$ limits for FSH and LH concentration of anterior pituitaries of a particular treatment group.

Because of the very low concentration and small amount of FSH in bovine anterior pituitaries, each pituitary was tested at a single dose only. The use of a single dose is based on the assumption that dose-response curves for bovine anterior pituitaries do not depart significantly (at $P=0.05$ ) from parallelism with the reference preparation (NIH-FSH-S1). This assumption has been tested in several trials with bovine anterior pituitaries as part of other studies with this species. As an example, Table 2 demonstrates that the dose-response curves for five bovine anterior pituitaries (obtained from ovariectomized cows) and the curve for the reference preparation NIH-FSH-S1 (ovine) were not significantly 'non-parallel' $(P=0 \cdot 25)$. For this test of validity, the 'pooled slope', based on the responses to all the substances in the assay, was used. However, even a comparison of the slopes for the reference preparation (NIH-FSH$\mathrm{S} 1$ ) and the 'Anterior-pituitary No. 5', which produced the flattest slope in the assay, failed to demonstrate a significant non-parallelism $(P=0 \cdot 10)$ within the limits of the error of the assay.

In a very large number of assays for LH activity, we have observed significant 
departures from parallelism no more frequently than would be expected by chance alone, between the dose-response curves for bovine anterior pituitaries and the reference preparation (NIH-LH-Sl, ovine).

The effect of castration and stilboestrol implantation on the concentration of FSH and LH in anterior pituitaries of grade Hereford bulls

The concentration of FSH in the anterior pituitary of nine untreated grade Hereford bulls was unusually low, ranging from 0.9 to $2.1 \mu \mathrm{g} / \mathrm{mg}$ dry weight. The mean value was $1.4 \mu \mathrm{g} / \mathrm{mg}$ (Table 3 ). On the other hand, values for LH concentration were relatively high, ranging from 8 to $13 \mu \mathrm{g} / \mathrm{mg}$, with a mean of $10.5 \mu \mathrm{g} / \mathrm{mg}$.

Table 2. Evidence for the validity of the use of NIH-FSH-S1 (ovine) as a reference preparation for the Steelman-Pohley bioassay of unfractionated bovine anterior pituitaries

\begin{tabular}{l|r|r|l}
\hline \multirow{2}{*}{ Preparation } & \multirow{2}{*}{ Total dose } & \multicolumn{2}{|c}{ Response (ovarian wt in mg) } \\
\cline { 3 - 4 } & & Mean & \multicolumn{1}{|c}{ Individuals } \\
\hline Saline (+HGG, 50 i.u.) & $3 \mathrm{ml}$ & 60 & $75,53,55,55$ \\
NIH-FSH-S1 & $75 \mu \mathrm{g}$ & 111 & $120,106,106,92,129$ \\
(+HCG, 50 i.u.) & $150 \mu \mathrm{g}$ & 180 & $160,181,127,207,226$ \\
Anterior pituitary No. 1 & $20 \mathrm{mg}$ & 123 & 95,150 \\
(+HCG,50 i.u.) & $40 \mathrm{mg}$ & 174 & 185,163 \\
Anterior pituitary No. 2 & $20 \mathrm{mg}$ & 103 & 135,70 \\
(+HCG, 50 i.u.) & $40 \mathrm{mg}$ & 163 & 158,168 \\
Anterior pituitary No. 3 & $20 \mathrm{mg}$ & 112 & 140,83 \\
(+HGG,50 i.u.) & $40 \mathrm{mg}$ & 148 & 156,139 \\
Anterior pituitary No. 4 & $20 \mathrm{mg}$ & 107 & 108,106 \\
(+HGG,50 i.u.) & $40 \mathrm{mg}$ & 156 & 133,178 \\
Anterior pituitary No. 5 & $20 \mathrm{mg}$ & 121 & 136,105 \\
(+HGG,50 i.u.) & $40 \mathrm{mg}$ & 148 & 152,144 \\
\hline
\end{tabular}

Pooled standard deviation $=27.97$.

Pooled slope $=176 \cdot 30$

$\lambda=0 \cdot 159$.

Departure from parallelism: not significant $(P>0 \cdot 25)$.

The effect of castration, at a mean age of 91 days, on the concentration of FSH and LH in the male bovine anterior pituitary is summarized in Table 3. Castration significantly increased FSH to a mean value, for ten steers, of 3.3 $\mu \mathrm{g} / \mathrm{mg}$, but did not increase the concentration of $\mathrm{LH}$. The mean value for $\mathrm{LH}$ concentration in these steers, $4 \cdot 3 \mu \mathrm{g} / \mathrm{mg}$, was much lower than the LH concentraion in the bull anterior pituitary.

Implantation of stilboestrol in the bulls had no significant effect on either FSH or LH concentration (Table 3). The mean FSH concentration for this group was computed on the basis of all the positive values determined. The FSH value for animal No. 27, less than $1.0 \mu \mathrm{g} / \mathrm{mg}$, was not included in the computation of the mean. However, it is assumed that the correct mean FSH for the entire group of stilboestrol-treated bulls is less than $2 \cdot 1 \mu \mathrm{g} / \mathrm{mg}$. It should also be noted that stilboestrol did not affect the weight of the testes of the bulls which 
Table 3. Concentration and comparison of FSH and $\mathrm{LH}$ in anterior pituitaries of grade Hereford, untreated bulls and steers, and bulls and steers with stilboestrol implants

\begin{tabular}{|c|c|c|c|c|c|}
\hline Treatment group & $\begin{array}{c}\text { Animal } \\
\text { no. }\end{array}$ & $\begin{array}{l}\text { No. of } \\
\text { LH } \\
\text { assays }\end{array}$ & $\begin{array}{c}\text { Mean LH } \\
\text { concentration* } \\
(\mu g / m g d r y w t)\end{array}$ & $\begin{array}{l}\text { No. of } \\
\text { FSH } \\
\text { assays }\end{array}$ & $\begin{array}{c}\text { Mean FSH } \\
\text { concentration* } \\
(\mu g / m g d r y w t)\end{array}$ \\
\hline $\begin{array}{l}\text { Untreated bulls } \\
\text { Group means }\end{array}$ & $\begin{array}{l}1 \\
2 \\
3 \\
4 \\
5 \\
6 \\
7 \\
8 \\
9\end{array}$ & $\begin{array}{l}3 \\
2 \\
2 \\
2 \\
2 \\
3 \\
3 \\
2 \\
2\end{array}$ & $\begin{array}{c}11 \text { (5 to } 25) \\
8(6 \text { to } 11) \\
8 \text { (5 to } 12) \\
13(9 \text { to } 19) \\
11(7 \text { to } 16) \\
12(7 \text { to } 22) \\
11(5 \text { to } 28) \\
10(7 \text { to } 13) \\
12(7 \text { to } 21) \\
10.5(9 \cdot 3 \text { to } 11 \cdot 9)\end{array}$ & $\begin{array}{l}2 \\
2 \\
1 \\
1 \\
2 \\
2 \\
1 \\
1 \\
1\end{array}$ & $\begin{array}{l}1.7(1.3 \text { to } 2.3) \\
1.3(0.9 \text { to } 1.9) \\
1.3(0.8 \text { to } 2.1) \\
1.7(1.1 \text { to } 2.7) \\
2.1(1.0 \text { to } 2.8) \\
2.0(1.4 \text { to } 2.8) \\
0.9(0.6 \text { to } 1.5) \\
1.6(1.0 \text { to } 2.5) \\
0.9(0.5 \text { to } 1.4) \\
1.4(1.1 \text { to } 1.7)\end{array}$ \\
\hline Untreated steers & $\begin{array}{l}10 \\
11 \\
12 \\
13 \\
14 \\
15 \\
16 \\
17 \\
18 \\
19\end{array}$ & $\begin{array}{l}2 \\
2 \\
3 \\
3 \\
2 \\
2 \\
2 \\
3 \\
2 \\
2\end{array}$ & $\begin{array}{l}4(3 \text { to } 7) \\
4(3 \text { to } 5) \\
5(3 \text { to } 8) \\
4(2 \text { to } 8) \\
5(3 \text { to } 7) \\
4(2 \text { to } 6) \\
5(4 \text { to } 6) \\
4(2 \text { to } 11) \\
3(2 \text { to } 5) \\
6(4 \text { to } 8) \\
4 \cdot 3(3.9 \text { to } 4 \cdot 8)\end{array}$ & $\begin{array}{l}1 \\
3 \\
2 \\
2 \\
2 \\
1 \\
1 \\
1 \\
1 \\
2 \\
2\end{array}$ & $\begin{array}{l}3.7(2.6 \text { to } 5.3) \\
4.1(2.7 \text { to } 6.3) \\
4.9(3.4 \text { to } 7.0) \\
3.2(2.3 \text { to } 4.5) \\
3.2(2.2 \text { to } 4.6) \\
2.6(1.4 \text { to } 5.0) \\
2.1(1.1 \text { to } 4.1) \\
1.9(1.3 \text { to } 2.8) \\
3.5(2.0 \text { to } 6.2) \\
5.5(3.8 \text { to } 7.9) \\
3.3(2.7 \text { to } 4.1)\end{array}$ \\
\hline $\begin{array}{l}\text { Bulls with } \\
\text { stilboestrol } \\
\text { implants }\end{array}$ & $\begin{array}{l}20 \\
21 \\
22 \\
23 \\
24 \\
25 \\
26 \\
27 \\
28 \\
29\end{array}$ & $\begin{array}{l}2 \\
2 \\
2 \\
2 \\
2 \\
2 \\
2 \\
2 \\
2 \\
2\end{array}$ & $\begin{array}{c}6(4 \text { to } 10) \\
11(8 \text { to } 15) \\
13(7 \text { to } 22) \\
9(6 \text { to } 14) \\
4(2 \text { to } 6) \\
12(8 \text { to } 17) \\
13(9 \text { to } 18) \\
11(8 \text { to } 16) \\
9(6 \text { to } 12) \\
8(6 \text { to } 11) \\
8.9(7.0 \text { to } 11 \cdot 4)\end{array}$ & $\begin{array}{l}1 \\
1 \\
2 \\
1 \\
1 \\
1 \\
1 \\
1 \\
1 \\
1\end{array}$ & $\begin{array}{r}1.3(0.7 \text { to } 2.3) \\
2.3(1.3 \text { to } 4.0) \\
4.5(3.2 \text { to } 6.3) \\
2.9(1.6 \text { to } 5.1) \\
2.1(1.2 \text { to } 3.7) \\
2.5(1.7 \text { to } 3.6) \\
1.3(0.7 \text { to } 2.5) \\
<1.0 \quad(1.2 \text { to } 2.6) \\
1.8(1.2 \text { to } 2.7) \\
1.4(0.7 \text { to } \\
<2.1(1.6 \text { to } 2.7)\end{array}$ \\
\hline $\begin{array}{l}\text { Steers with } \\
\text { stilboestrol } \\
\text { implants }\end{array}$ & $\begin{array}{l}30 \\
31 \\
32 \\
33 \\
34 \\
35 \\
36 \\
37 \\
38 \\
39 \\
40\end{array}$ & $\begin{array}{l}2 \\
2 \\
2 \\
2 \\
2 \\
2 \\
2 \\
3 \\
2 \\
3 \\
3 \\
2\end{array}$ & $\begin{array}{l}5(3 \text { to } 8) \\
6(4 \text { to } 8) \\
6(4 \text { to } 10) \\
5(4 \text { to } 6) \\
6(5 \text { to } 8) \\
6(4 \text { to } 8) \\
7(4 \text { to } 12) \\
7(5 \text { to } 10) \\
7(4 \text { to } 13) \\
5(3 \text { to } 9) \\
7(5 \text { to } 9) \\
6.0(5.5 \text { to } 6.6)\end{array}$ & $\begin{array}{l}1 \\
2 \\
2 \\
1 \\
1 \\
1 \\
1 \\
3 \\
2 \\
2 \\
1\end{array}$ & $\begin{array}{l}4.7(3.2 \text { to } 6.9) \\
4.7(3.3 \text { to } 6.6) \\
6.3(4.5 \text { to } 8.9) \\
3.8(2.6 \text { to } 5.5) \\
3.8(2.0 \text { to } 7.2) \\
2.8(1.5 \text { to } 5.3) \\
2.7(1.9 \text { to } 3.9) \\
4.7(3.4 \text { to } 6.4) \\
5.4(3.8 \text { to } 7.6) \\
4.8(3.4 \text { to } 6.8) \\
4.3(2.3 \text { to } 8.1) \\
4.1(3.4 \text { to } 5.0)\end{array}$ \\
\hline & & & & & \\
\hline
\end{tabular}

* Expressed in terms of NIH-LH-S1 and NIH-FSH-SI (mean values, with 95\% confidence limits in parentheses).

received implants (Bailey, Probert \& Bohman, 1966). Stilboestrol implants in the steers failed to influence the concentration of FSH, but did produce a statistically significant, though only slight, increase in the LH concentration. 
The effect of stilboestrol on the concentration of FSH and LH in anterior pituitaries of purebred Hereford bulls

Untreated pure-bred Hereford bulls appeared to differ little from grade Herefords as far as the concentration of $\mathrm{FSH}$ and $\mathrm{LH}$ in their anterior pituitaries was concerned. The mean values, $2.1 \mu \mathrm{g} / \mathrm{mg}$ for FSH and $13.5 \mu \mathrm{g} / \mathrm{mg}$ for LH, were significantly $(P<0.05)$ but only slightly higher than the corresponding mean values for grade Herefords (Table 4). As in the case of the grade Herefords, stilboestrol implantation in the pure-bred Herefords failed to affect significantly either FSH or LH concentration or the weight of the testes.

Table 4. Concentration and comparison of FSH and LH in anterior pituitaries of pure-bred Hereford, untreated bulls, and bulls with stilboestrol implants

\begin{tabular}{|c|c|c|c|}
\hline $\begin{array}{l}\text { Treatment } \\
\text { group }\end{array}$ & $\begin{array}{l}\text { No. of } \\
\text { animals }\end{array}$ & $\begin{array}{c}\text { Mean } L H \\
\text { concentration* } \\
(\mu g / m g d r y \text { wot })\end{array}$ & $\begin{array}{c}\text { Mean FSH } \\
\text { concentration } \\
(\mu g / m g d r y w t)\end{array}$ \\
\hline Untreated bulls & $10 \dagger$ & $13.5(11.3$ to 16.2$)$ & $2 \cdot 1(1.6$ to $2 \cdot 7)$ \\
\hline $\begin{array}{l}\text { Bulls with stilboes- } \\
\text { trol implants }\end{array}$ & $8 \dagger$ & $12.1(10.1$ to 14.5$)$ & $2.0(1.4$ to $2 \cdot 7)$ \\
\hline
\end{tabular}

* Expressed in terms of NIH-LH-S1 (mean values, with $95 \%$ confidence limits in parentheses). LH.

$\dagger$ Each pituitary in the group was assayed individually for both FSH and

Concentration and ratio of FSH and LH in anterior pituitaries of adult males of three different mammalian species

A comparison of bull pituitary FSH concentration with that of four groups of normal adult male rats (Holtzman strain: Holtzman Co., Madison, Wisconsin) revealed that the ratio of FSH concentrations in these two species was approximately 1:100 (Table 5). There was approximately as much FSH in one male rat pituitary as in one bull pituitary. It was primarily for this reason that the ratio of FSH/LH concentration in bull pituitaries was much lower than the corresponding ratio in male rat pituitaries. It should be noted that male bovine pituitary LH concentration is higher than male rat pituitary LH. Analysis of a single available male pig pituitary revealed an $\mathrm{FSH} / \mathrm{LH}$ ratio which was closer to that of the male rat than to that of the male bovine.

\section{DISGUSSION}

Studies presenting a quantitative evaluation of pituitary FSH and $\mathrm{LH}$ in bovine pituitary glands by means of differential bioassays have been relatively few (Labhsetwar, Collins, Tyler \& Casida, 1964a, b; Rakha \& Robertson, 1965; Macmillan \& Hafs, 1968). Only one previous study (Macmillan \& Hafs, 1968) has suggested the validity of the use of an ovine FSH reference preparation for the bioassay of unfractionated bovine pituitaries by the HCG-augmentation method and an ovine or bovine LH reference preparation for the bioassay 


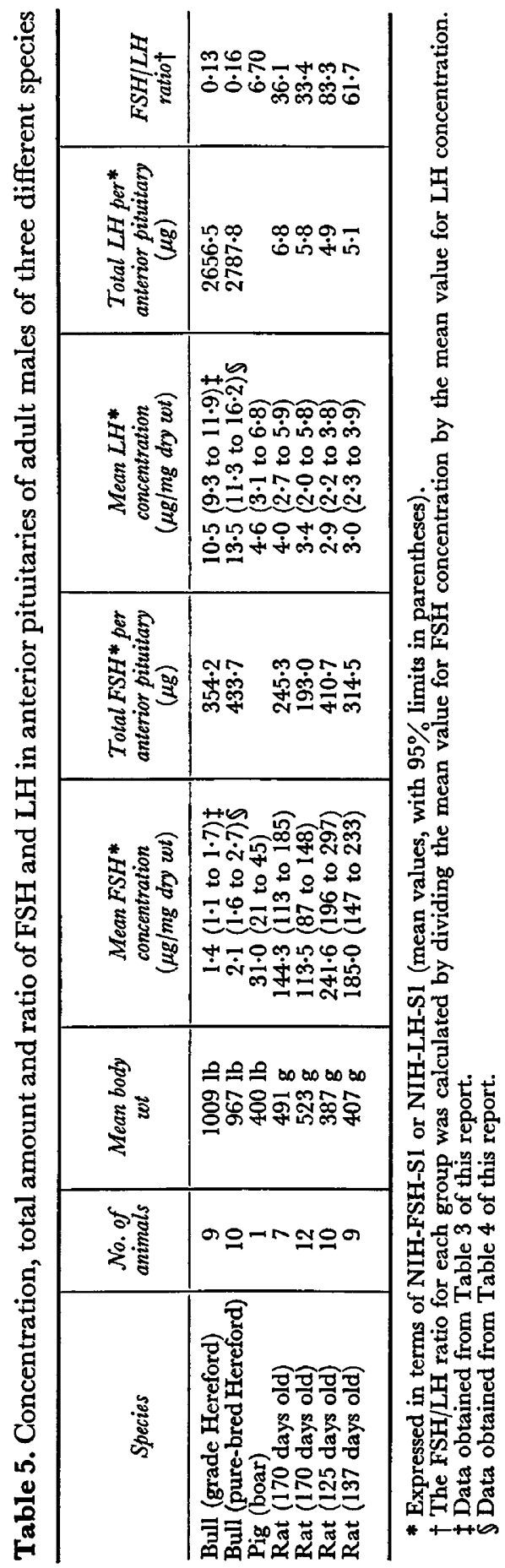


of such pituitaries by the OAAD method. The data in our report establish this validity.

The present study is unique among all efforts to evaluate bovine pituitary FSH and LH, in that each pituitary gland was tested individually for both FSH and $\mathrm{LH}$ activities. Among untreated bulls, a considerable degree of uniformity in pituitary FSH concentration (range: 0.9 to $2.0 \mu \mathrm{g}$ NIH-FSH-S1/mg dry weight) and pituitary LH concentration ( 8 to $13 \mu \mathrm{g}$ NIH-LH-S1/mg) existed. Among untreated steers, $\mathrm{LH}$ concentration ( 3 to $6 \mu \mathrm{g} / \mathrm{mg}$ ) was relatively uniform, while FSH concentration $(1.9$ to $5.5 \mu \mathrm{g} / \mathrm{mg})$ varied to a somewhat greater degree.

Pituitary FSH and LH concentrations in the untreated male bovine were similar to those reported for the normally cycling cow (Rakha \& Robertson, 1965), suggesting that there is no large sex difference with respect to pituitary gonadotrophin concentrations in this species.

The total amount of FSH in the male bovine pituitary determined in this study was slightly higher than that observed by Macmillan \& Hafs (1968). A possible explanation for this discrepancy is the difference in age of the animals: approximately 18 months in this study, but only 12 months in their study (Macmillan \& Hafs, 1968).

The magnitude of the species difference in pituitary FSH concentrations in the male bovine and male rat is surprising. A 100-fold difference in FSH concentration exists.

Much more surprising, however, is the nature of the changes in male bovine pituitary FSH and LH concentrations in response to gonadectomy. Thus, in the male rat, it is well established that the long-term effect of gonadectomy is a large increase in pituitary LH concentration to a level approximately five to ten times higher than that of intact males (Parlow, 1964a; Bogdanove, Parlow, Bogdanove, Bhargava \& Crabill, 1964). This elevation persists, according to our observations, for at least 1 year. Steer pituitary LH concentration, measured approximately 1 year after gonadectomy, was substantially lower than that of the pituitary from 'intact' bulls.

The observed effect of long-term gonadectomy in lowering pituitary LH concentration in the male bovine, in contrast to the pituitary LH-elevating effect of gonadectomy in the male rat, lends support to the concept that there are species differences in the mode of regulation of pituitary gonadotrophin concentration. This concept had first been proposed in a previous study of the female mouse, in which long-term gonadectomy had no observable effect on pituitary LH concentration (Parlow, 1964b).

The somewhat higher concentration of FSH in the steer than in the bull anterior pituitary is more nearly in accord with the 'expected' response of pituitary gonadotrophins to long-term gonadectomy.

The nature of the changes in either pituitary FSH or LH concentration in response to gonadectomy presented in this report are not, and should not be, interpreted to signify that similar, or different, alterations in serum levels of FSH and LH occur. The changes in pituitary gonadotrophin concentrations are merely one aspect of the response of gonadotrophins to gonadectomy, an aspect which should be compared with serum levels of FSH and LH. 


\section{AGKNOWLEDGMENTS}

Supported by NIH grant AM 11214, Career Development Award AM 7735, and Ford Foundation grant 67-514.

\section{REFERENGES}

Bailey, C. M., Probert, G. L. \& Bohman, V. R. (1966) Growth rate, feed utilization and body composition of young bulls and steers. F. Anim. Sci. 25, 132.

Burss, G. I. (1952) The statistics of bioassays. Academic Press, New York.

Bogdanove, E. M., Parlow, A. F., Bogdanove, J. N., Bhargava, I. \& Grabill, E. V. (1964) Specific LH and FSH bio-assays in rats with hypothalamic lesions and accessory sex gland hypertrophy. Endocrinology, 74, 114.

Labhsetwar, A. P., Collins, W. E., Tyler, W. J. \& Casida, L. E. (1964a) Effect of progesterone and oxytocin on the pituitary-ovarian relationship in heifers. F. Reprod. Fert. 8, 77.

Labhsetwar, A. P., Collins, W. E., Tyler, W. J. \& Gasida, L. E. (1964b) Some pituitary-ovarian relationships in the periparturient cow. F. Reprod. Fert. 8, 85.

Macmillan, K. L. \& Hafs, H. D. (1968) Pituitary and hypothalamic endocrine changes associated with reproductive development of Holstein bulls. F. Anim. Sci. 27, 1614.

Parlow, A. F. (1961) Bio-assay of pituitary luteinizing hormone by depletion of ovarian ascorbic acid. In: Human Pituitary Gonadotropins, p. 301. Ed. A. Albert. Charles C. Thomas, Springfield, Illinois.

Parlow, A. F. (1964a) Comparison of pituitary and serum gonadotrophins of the rat. Endocrinology, 74, 489 .

Parlow, A. F. (1964b) Effect of ovariectomy on pituitary and serum gonadotropins in the mouse. Endocrinology, 74, 102.

Parlow, A. F. \& Reichert, L. E., JR (1963) Species differences in follicle stimulating hormone as revealed by the slope in the Steelman-Pohley assay. Endocrinology, 73, 740.

Rakha, A. M. \& Robertson, H. A. (1965) Changes in levels of follicle stimulating hormone and luteinizing hormone in the bovine pituitary gland at ovulation. F. Endocr. 31, 245.

SHePs, M. G. \& Moore, E. A. (1960) Methods for combining the results of two biological assays. $\mathcal{F}$. Pharmac. exp. Ther. 128, 99.

Steelman, S. L. \& Pohley, F. M. (1953) The assay of the follicle stimulating hormone based on augmentation with human chorionic gonadotropin. Endocrinology, 53, 604. 